\title{
Climate Change, Its Effect on Livestock Production and Adaptation Strategies in Hawassa Zuria and Hula Districts of Sidama Region, Southern Ethiopia
}

\author{
Tsige Fiseha Lomiso \\ Department of Climate Change and Sustainable Agriculture, Hawassa University, Hawassa, Ethiopia \\ Email address: \\ tsigefiseha07@gmail.com \\ To cite this article: \\ Tsige Fiseha Lomiso. Climate Change, Its Effect on Livestock Production and Adaptation Strategies in Hawassa Zuria and Hula Districts of \\ Sidama Region, Southern Ethiopia. International Journal of Environmental Monitoring and Analysis. Vol. 8, No. 5, 2020 , pp. 117-129. \\ doi: 10.11648/j.ijema.20200805.11
}

Received: August 3, 2020; Accepted: August 17, 2020; Published: September 3, 2020

\begin{abstract}
Climate change remains the major threat for livelihood of smallholder farmers in Ethiopia. This study reviews the effects of climate change on livestock production and adaptation measures employed by the farmers from two districts in Sidama Region. The data was collected from 189 sample households. The climate data were collected from National Meteorological Agency. The results revealed that the trend of RF was increasing by the rate of $0.79 \mathrm{~mm}$ in Hawassa Zuria and $11.62 \mathrm{~mm}$ in Hula per annum and there are tendencies indicating a future with warmer climate. The effects of climate change were reduced quality and quantity of feed, increased incidence of diseases, reduced quality and quantity of water and reduced production and reproduction performance of animals. From the total households $27 \%$ of the sample households were practicing reducing the number of animals in Hawassa Zuria and income diversification adaptation strategies in Hula. Adaptation strategies considered in the Multinomial logit model analysis were income diversification, supplementary feed, reducing number of animals and diversifying animals. Education, age, labor size, farm size of household and livestock holding are among the factors that might contribute to explain different levels of adaptive capacity within these two communities. Therefore, future policy should focus on improving the quality of meteorological data, water supply, enhancing innovations in livestock production system and enhancing research on use of new improved forage species.
\end{abstract}

Keywords: Adaptation, Climate Change, Multinomial Logit Model

\section{Introduction}

Climate change is one of the biggest environmental challenges and it has become a major concern to society because of its potentially adverse impacts worldwide. There are already increasing concerns globally regarding climate change is threatening the livelihoods of the vulnerable population segments $[58,59]$.

According to the climate change vulnerability index in 2014 , Ethiopia ranks $10^{\text {th }}$ in the list of countries most at risk of climate change. The low-level of development and dependence on agriculture are the main reasons for the vulnerability [60]. Climate variability and extreme events are causing significant damage to life, property, natural resources and economy in Ethiopia; making the most important economic systems highly vulnerable [16].
Climate affects livestock production directly and indirectly [28]. Direct impacts of climate change on animals are: Heat stress [54] milk yield reduction and poor reproduction performance $[44,60]$. The indirect effects are on: quality and amount of fodder $[8,42]$, availability and quality of water [5, $61]$, animal health $[28,38,61]$ and genetic diversity of animals [ 8, 18, 26, 42, 49].

To minimize the impact of climate change on smallholder farmers, adaptation strategies are vital instruments [12, 15, 25, 47]. Therefore, efforts should focus on finding mechanisms in which livestock keepers can reduce these problems and improve smallholder farmers' adaptation strategies to climate change in order to enhance resilience of the sector.

Climate change will have far-reaching consequences for animal production, especially in vulnerable parts of the 
world. The impact of climate change can heighten the vulnerability of livestock systems and exacerbate existing stresses upon them, such as drought [19].

Animals are the means of asset building, insurance, savings, and important source of food for Sidama people [34]. Sidama's rural livelihoods are at risk due to several factors, an important one being climate change. Weather conditions in the highlands are gradually converting to midland conditions while the lowlands tend to transform into semi-desert [45]. Sidama experienced food insecurity, diminishing water resources, drought, erratic and torrential rainfall causing flood and the constellation of marginality all worsened by climatic stress [32].

Livestock production system is sensitive to climate and responding to the challenges requires formulation of appropriate adaptation options for the sector [37]. This study, therefore, identifies the effects of climate change on livestock production and possible adaptation measures taken by farmers in highlands and lowlands of Sidama region.

\section{Methodology}

\subsection{Description of the Study Area}

The study was conducted in Hawasa Zuria and Hula woredas (districts) of Sidama region (Figure 1). The dominant agricultural production system in the study area is smallholder mixed crop-livestock systems. Hawasa Zuria district is found in the great rift valley of Ethiopia and bordered on the south by Shabadino and Boricha, on the west and north by the Oromia Region, and on the east by Wondo Genet. This district almost surrounds Lake Hawasa on all sides. Based on the Census conducted by the CSA, this district has a total population of 124,472 , of whom 62,774 are male and 61,698 females.

Hula district is found in the highlands of Sidama Regional State at $98 \mathrm{~km}$ South of Hawassa city. It is bordered by Oromia Region on the South, Bursa district on the North and Bona zuria on the East. The district has population of 129,263 of whom 64,551 are men and 64,712 women.

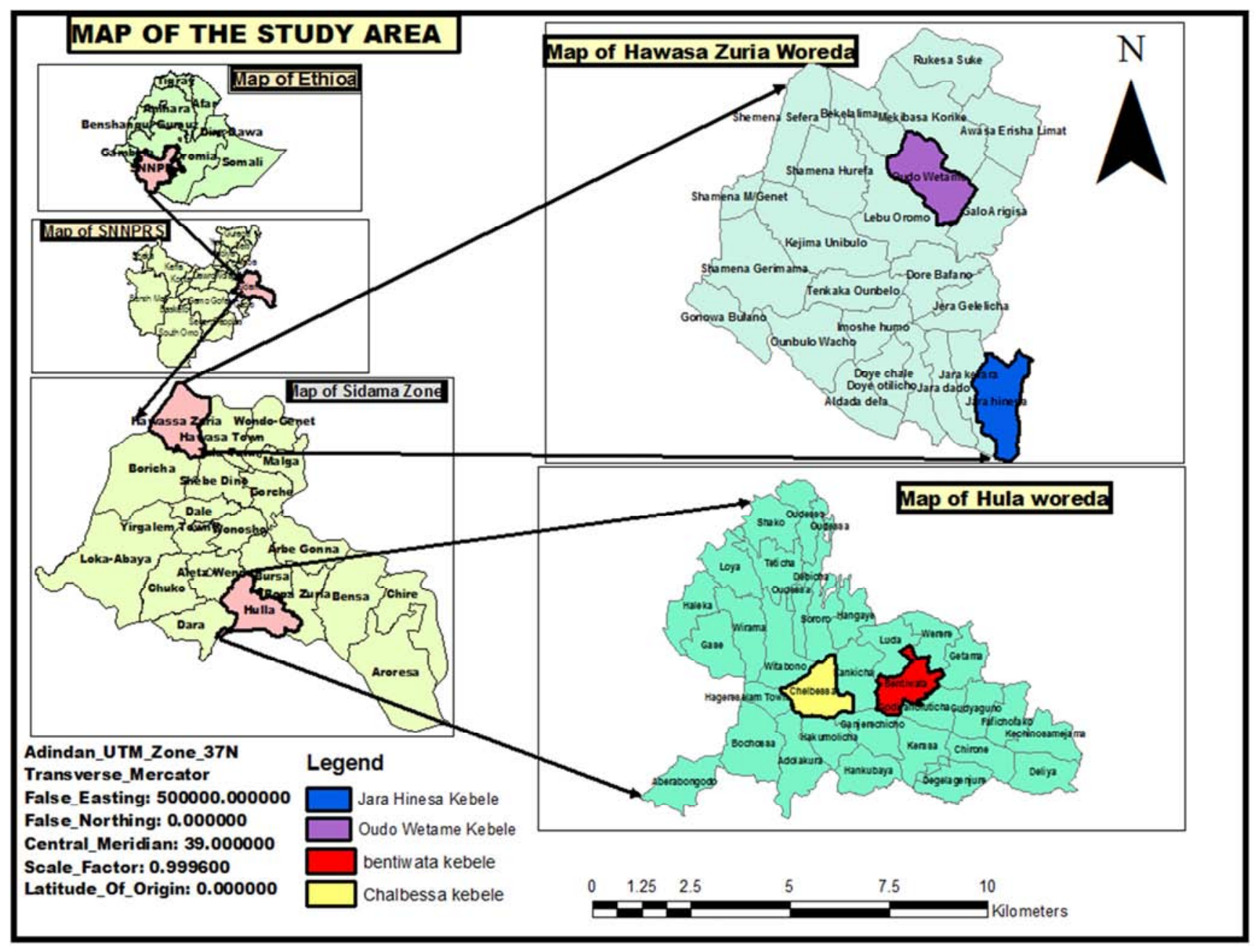

Figure 1. Location map of the study areas.

\subsection{Sampling Procedure}

The selection of study area is predicated on spatial difference, which links to the fact that vulnerability and impacts of climate change and hence adaptation measures vary from place to place. Altitude is the key influence on livelihood systems, farming practices, human settlement, 
rainfall distribution and temperature. Accordingly, two AEZs were selected representing lowlands, and highlands. Thus, Jara Hi'nessa and Udo Wotate kebeles from Hawassa Zuria district (representing lowland) and Bantiwata and Chalbessa kebeles from Hula district (representing highland) were selected randomly out of 23 and 31 kebeles respectively. Then, sample households were selected using systematic random sampling technique. Lists of total households were acquired from each kebele administers. Simplified formula provided by Yamane was used to determine the required sample size at $95 \%$ confidence level and $7 \%$ level of precision as shown below.

$$
\mathrm{n}=\frac{\mathrm{N}}{1+\mathrm{N}(e)^{2}}=\frac{2475}{1+2475(0.07)^{2}} \approx 189
$$

Where $\mathrm{n}$ is sample size, $\mathrm{N}$ is total households of selected kebeles and e is precision level.

Both primary and secondary data sources were used. The data on effects of climate change on livestock production, adaptation strategies and determinants were collected through questionnaires directly from sample households, focus group discussions and key informants. Metrological data were gathered from National metrological agency Hawassa branch directorate.

At the Hula (Hagereselam) meteorological station's recording system is poor; from 31 years' records, some years have missed records for two to six months. Years that have such restrictions of records have been fulfilled based on the climatological data estimation method which assumes that a missing value equals the average of measurements taken at the same time in other years.

Climate change can be observed by the long term weather elements like temperature and precipitations. In this regards based on data from National Meteorology agency maximum and minimum temperature and precipitation data of the study districts were analyzed to observe the trends in climate change [58].

\subsection{Data Collection Procedure}

Household survey: - Semi-structured questionnaires were prepared and the sample households of both AEZs were interviewed about the climate change, its impact on livestock production and the adaptation measures. Data collection was carried out by applying face to face interview of researcher with farmers.

Key informant interviews (KII): - The interview was carried out with a total of 10 key informant interviewees which have included 4 DAs (one from each kebele), 4 elder informants (one from each kebele) and 2 woreda livestock office expert (one from each district).

Focus group discussions (FGDs): - Both male and female farmers representing different age groups, with different education level and wealth groups were selected from each sample kebeles. Local, relative wealth status ranking method was used to identify wealth groups; which suggest that a household is poor or rich in the context of its village. Total of eight FGDs were conducted on (two focus group discussions in each kebele with 6 participants in each FGD).

\subsection{Methods of Data Analysis}

Both descriptive statistics and econometric model were used to analyse collected data. Tables, percentages, frequency, graphs and mean values were used to present the analysed data. Data collected from the two different AEZs were analysed separately in order to contrast the results. Independent samples $t$ - test was used to compare the observation of the two districts.

To analyse data type of adaptation measures and its determinants, multinomial logit model (MNL) was used. Trends of rainfall and temperature were analysed by undertaking linear trend analysis and also Mann-Kendall test for trend significance was used. Rainfall data were analysed by Standard Precipitation index (SPI) and Coefficient of Variation. SPI is used to quantify the precipitation deficit for multiple timescales.

$$
\mathrm{SPI}=\frac{\mathrm{X}-\overline{\mathrm{X}}}{\mathrm{SD}}
$$

Where SPI is Standardized Precipitation Index, $\mathrm{X}$ is discrete precipitation data, $\bar{X}$ is mean and SD is Standard Deviation

SPI is drought index which is a powerful, flexible and simple to calculate. In addition, it is just as effective in analysing wet periods as it is in analysing dry periods. It indicates the moisture level from extremely wet $(\mathrm{SPI} \geq 2)$ to extremely dry (SPI $\leq-2)$ [35]. SPI is based on the probability of precipitation for any time scale. The probability of observed precipitation is then transformed into an index. It is being used in research or operational mode in more than 70 countries [62].

Intra seasonal rainfall variability was analysed using the coefficient of variation $(\mathrm{CV})$.

$$
\mathrm{CV}=\frac{\mathrm{SD}}{\overline{\mathrm{X}}} \times 100
$$

Where CV is Coefficient of Variation; SD is Standard Deviation

The non-parametric Man-Kendall test used to determine whether there was a positive or negative trend in weather data with their statistical significance [36] Therefore, MannKendall trend test was applied to detect the presence of trends in the precipitation and temperature records for Hawassa Zuria and Hula districts.

The test statistic (S) for the Mann-Kendall test is given as:

$$
\sigma_{s}=\frac{\sqrt{N(N-1)(2 N+5)-\sum_{i=1}^{N} t i(i-1)(2 i+5)}}{18}
$$

Where: $\mathrm{N}$ is the number of data, $\mathrm{Yj}$ and $\mathrm{Yi}$ are the data values in two consecutive periods; ti is the number of ties, i.e. equal values, of extent $\mathrm{i}$ and $\mathrm{N}$ is the number of tied groups.

The function $\operatorname{sign}\left(\mathrm{Y}_{\mathrm{j}}-\mathrm{Y}_{\mathrm{i}}\right)=1$ if $\mathrm{Y}_{\mathrm{j}}-\mathrm{Y}_{\mathrm{i}}>0$; $\operatorname{sign}\left(\mathrm{Y}_{\mathrm{j}}-\mathrm{Y}_{\mathrm{i}}\right)=0$ if $\mathrm{Y}=0$ and $\operatorname{sgn}\left(\mathrm{Y}_{\mathrm{j}}-\mathrm{Y}_{\mathrm{i}}\right)=-1$ if $\mathrm{Y}_{\mathrm{j}}-\mathrm{Y}_{\mathrm{i}}<0$.

MNL model is appropriate to the model of climate 
change adaptation practice of smallholder farmers. To describe the model, let $\mathrm{Y}$ denoted vector of adaptation options for climate change to chosen by farmer household. Assuming the adaptation option farmers' choice are depending on climatic factors, institutional factors and socioeconomic characteristic of the farmers. The MNL model for the adaptation choice can be specified in the following relationship between the probability of choosing option and a set of explanatory variables [24].

$$
\operatorname{Prob}\left(Y_{i}=j\right)=\frac{e^{\beta^{\prime} j^{x i}}}{\sum_{k=0}^{5} e^{\beta \prime k^{x i}}}, \mathrm{j}=0,1,2 \ldots 5
$$

Equation (1) is normalized to remove indeterminacy in the model by assuming $\beta_{0}=0$ and the probabilities can be estimated as: -

$$
\operatorname{Prob}\left(Y_{i}=j / x_{i}\right)=\frac{e^{\beta^{\prime} j^{x i}}}{1+\sum_{k=0}^{J} e^{\beta^{\prime \prime} k^{x i}}}, \mathrm{j}=0,1,2 \ldots \mathrm{j}
$$

Maximum likelihood estimation of equation (2) yields the log-odds ratio

$$
\ln \left(\frac{P_{i j}}{P_{i k}}\right)=x^{\prime}{ }_{i}\left(\beta_{j}-\beta_{k}\right)=x^{\prime}{ }_{i} \beta_{j}, \text { if } \mathrm{k}=0
$$

The dependent variable of any adaptation option is therefore the log of odd in relation to the base alternative. MNL coefficients are difficult to interpret and associating the $\beta_{\mathrm{j}}$ with the $j^{\text {th }}$ outcome is tempting and misleading. Therefore, Marginal effect is useful to interpret the effect of independent variable on the dependent variable in terms of probabilities [24].

$$
\frac{\partial P_{j}}{\partial x_{i}}=P_{j\left(\beta_{j}-\sum_{k=0}^{J} P_{k} \beta_{J}\right)=P_{j}\left(\beta_{j}-\beta\right)},
$$

The marginal effects, measure the expected change in probability of a particular choice being made with respect to a unite change in explanatory variable [24].

Excel sheets, Statistical Packages for Social Scientists (SPSS) version 20 and STATA version 14.2 were used to raw data entry, analysing the data and present the findings.

\section{Results and Discussions}

\subsection{Climate Data Analysis of Hawassa Zuria and Hula}

Climate of a region is determined by temperature, precipitation, wind and cloud. Among these temperature and precipitation are major elements.

\subsubsection{Rainfall}

The trend analysis of the Meteorological data of rainfall over the past 31 years shows that there was slightly increasing trend in annual rainfall in the study areas, despite the perception of the majority of respondents. The recorded data of the areas showed in contrary of the most farmers' perception and indicated an increasing trend in rainfall in 31 years' period. The trends results show an increase of $0.79 \mathrm{~mm}$ and $11.62 \mathrm{~mm}$ of rainfall annually in Hawassa Zuria and Hula respectively from the year 1987 to 2017.

A research report indicated that observations on Meteorological station lack congruence with farmers' perception of trend in changing of climate elements. This lack of congruence could be due to the fact that farmers assess rainfall in relation to the needs of particular crops at particular times; small change in quality, onset and cessation of rain over days or even hours can make a big difference, whereas Meteorological data is more likely to measure total and large events [41]. The amount of rainfall has been decreasing in many areas of Ethiopia, but increasing in some areas [56].

According to IPCC there was an increasing of rainfall in parts of east Africa and the historical observed data also revealed which is similar with the results obtained in the study over Hawassa Zuria and Hula districts. Trend analysis of annual rainfall in Ethiopia shows that rainfall remained more or less constant when averaged over the whole country while a declining trend has been observed over the Northern and Southwestern Ethiopia [29].

The annual rainfall of Hawassa Zuria district in the years 1987-2017, ranges from $670.9 \mathrm{~mm}$ in 2015 (the driest year) to $1197.9 \mathrm{~mm}$ in 2006 (the wettest year). The mean annual rainfall of those years is about $959.3 \mathrm{~mm}$ with $\mathrm{SD}=141 \mathrm{~mm}$. Likewise the annual rainfall of Hula district, ranges from $973.6 \mathrm{~mm}$ (in 2003) to $1756.6 \mathrm{~mm}$ (in 2010). The mean annual rainfall was also about $1326.82 \mathrm{~mm}$ with $\mathrm{SD}=205.5 \mathrm{~mm}$.

Rainfall of the districts show inter annual variability over the past three decades. According to the result, annual rainfall of Hula was more variable than that of Hawassa Zuria. The change in seasonality, distribution and regularity of rainfall were becoming more of concern than the overall amount of rainfall. Even the main rainy season progressively become shorter some times in some areas; it starts later and stops earlier than it accustomed to.

The present result was consistent with findings that in East Africa regions across Ethiopia, Kenya, Somalia and Tanzania while mean temperature varied with elevation, the more remarkable climate variation was with respect to precipitation in a given area [27]. This variability has also been indicated as a major problem to livestock production as felt by respondents.

The rainfall in Ethiopia does not show any definite trend; it shows high variability $[3,11,17,57]$. Analysis of the annual total rainfall data of Ethiopia indicated a coefficient of variation ranging from 20 to $89 \%$ highlighting the extreme variability of rainfall over the country [3].

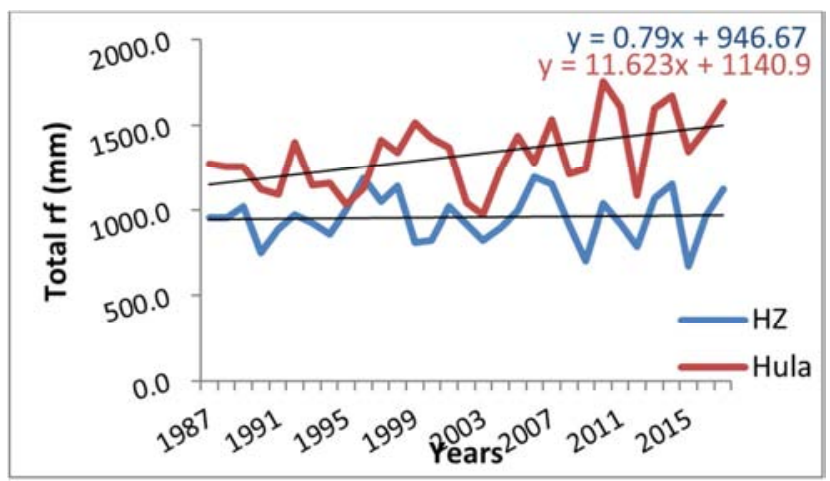

Figure 2. Annual rainfall trend in $H Z$ and Hula. 


\section{Seasonal rainfall trends and variability}

From meteorological point of view, there are three seasons in Ethiopia; Belg, Kiremt and Bega. Belg (February to May) is the small rainy season in Ethiopia. Much of the northeastern, central, southern, southwestern, eastern and southeastern parts of the country receive considerable amount of rainfall during this season. Kiremt (June to September) is the main rainfall season for most parts of the country except for the lowlands of southern and southeastern Ethiopia. Bega (October to January) is mostly a dry season for most parts of the country except for southwestern as well as the lowlands of south and southeast Ethiopia [39].

In Hawassa zuria district maximum and minimum rainfall of the main rainy season (Kiremt) in the last 31 years was $692.6 \mathrm{~mm}$ and $280 \mathrm{~mm}$ respectively. The mean rainfall was $460.3 \mathrm{~mm}$; with SD and CV of $105.46 \mathrm{~mm}$ and $22.9 \%$ respectively. In Hula district maximum and minimum rainfall of Kiremt was $918 \mathrm{~mm}$ and $316 \mathrm{~mm}$ respectively. The mean rainfall was $533.9 \mathrm{~mm}$ with SD of $137.93 \mathrm{~mm}$ and $\mathrm{CV}$ of $25.83 \%$.

In Hawassa zuria there was high inter-seasonal variability between the belg and kiremt rainfall. Rainfall of belg season has shown declining trend from 1987-2017. It has decreased by $0.67 \mathrm{~mm}$ per year over the past three decades. On the other hand, kiremt rainfall was increased by $2 \mathrm{~mm}$ per year. But in Hula both belg and kiremt rainfall has increased by $2.74 \mathrm{~mm}$ and $5.96 \mathrm{~mm}$ per year respectively.
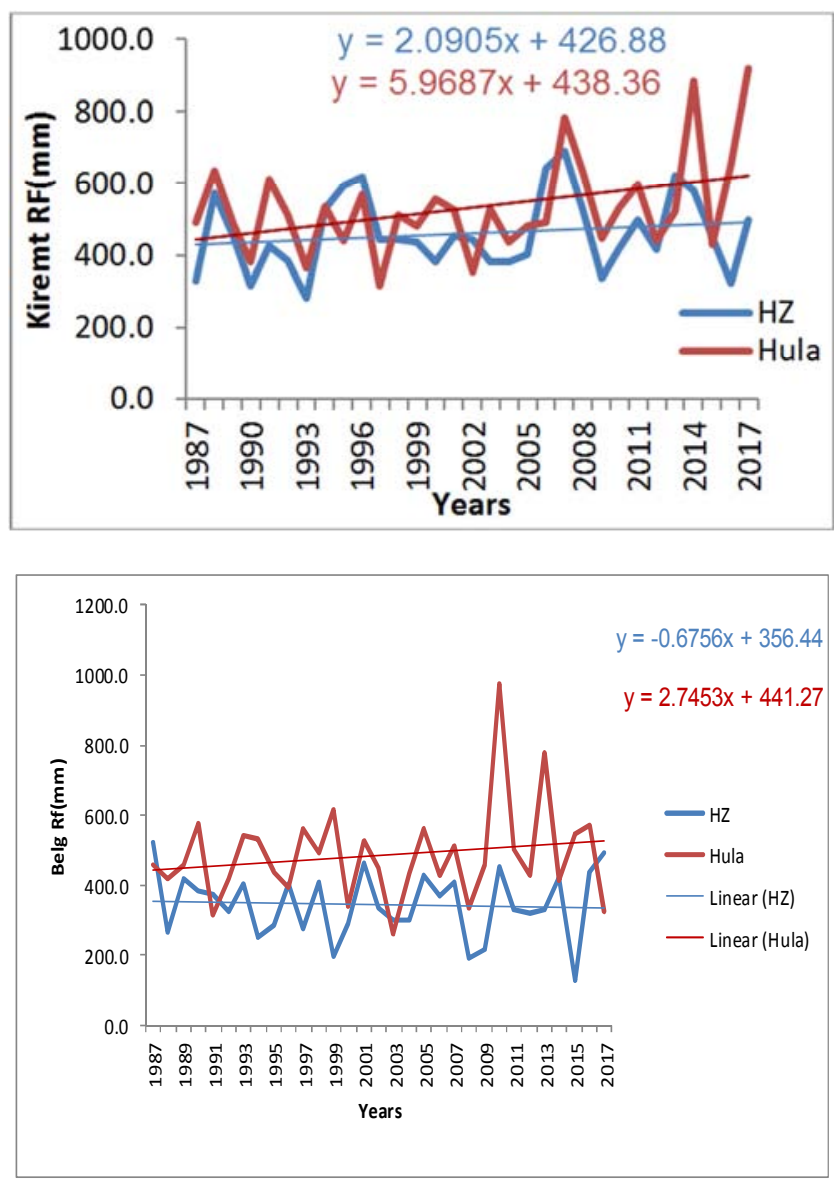

Figure 3. Kiremt and belg season rainfall trend in $\mathrm{HZ}$ and Hula.
On Figure 3 above, trend lines clearly indicate the increased pattern of rainfall in both districts. Thus, the seasonal rainfall during main rainy season revealed an increasing from time to time over the past three decades. The increasing trend of Kiremt rainfall could be the main cause for increasing of annual rainfall. Inversely, in case of short rainy season the trends analysis of the seasonal rainfall shows decreasing in rainfall amounts over time at Hawassa Zuria and slightly increasing at Hula district.

Short rainy season $($ Belg) rainfall extended from $125.7 \mathrm{~mm}$ to $521.8 \mathrm{~mm}$ in Hawassa Zuria and $260.5 \mathrm{~mm}$ to $975 \mathrm{~mm}$ in Hula district. The mean rainfall of Belg was $345.6 \mathrm{~mm}$ in Hawassa Zuria and $485.2 \mathrm{~mm}$ in Hula with SD 94.15 and 137.58 in respective districts. CV of Belg season was $27.24 \%$ in Hawassa Zuria and $28.35 \%$ in Hula, which lie within moderately variable category.

In particular, rains have decreased during the Belg season in the East and Southeast with the largest percent reductions [39]. According to Oxfam International [41], the rainfall data gathered from rift valley of Oromia meteorological station showed, in the last three to four decades, rainfall has become highly variable and erratic in terms of amount and distribution in the area. The short rainy season (Belg) has failed repeatedly in the past 20 years.

As shown in table 1 below, the rainfall of Hula is more variable than that of Hawassa zuria and Belg rainfall has relatively higher $\mathrm{CV}$ than total annual and Kiremt rainfalls in both districts. The annual rainfall was less variable whereas Kiremt and Belg rainfall was considered as moderately variable.

Table 1. Coefficients of variation.

\begin{tabular}{llll}
\hline Districts & Rainfall & Mean rainfall $(\mathbf{m m})$ & CV $\mathbf{( \% )}$ \\
\hline Hawassa Zuria & Total annual & 959.31 & 14.69 \\
& Belg & 345.6 & 27.24 \\
\multirow{4}{*}{ Hula } & Kiremt & 460.3 & 22.91 \\
& Total annual & 1326.82 & 15.48 \\
& Belg & 485.2 & 28.35 \\
& Kiremt & 533.9 & 25.83 \\
\hline
\end{tabular}

Standard precipitation index (SPI) as a Measure of Drought

Drought indicators based purely on precipitation give a good overall view of the situation. Correspondingly SPI has been used to classify degree of drought. Drought begins when the standardized rainfall anomaly first falls below zero and ends with the first positive value [35].

In Hawassa zuria and Hula districts annual rainfall is below average in 16 years out of 31 . Thus, this shows that both districts had been suffering from shortage of rainfall in the years more than a half out of the last three decades. Both districts had below average rainfall in the same 12 years out of 16. As indicated in figure 4 below, the droughts of 1990 , 1999 and 2012 in HZ and 1991, 1995, 2002 and 2012 in Hula categorized as moderate drought; their SPI values are $(-1.48$, $-1.06,-1.23,-1.12,-1.41,1.36$ and -1.16$)$, respectively.

Moreover, drought of 2009 in Hawassa Zuria and 2003 in Hula, were categorized as severe drought, their SPI values 
are (-1.81 and -1.72$)$, respectively. Based on the criterion Hawassa Zuria experienced extreme annual drought in 2015 $(\mathrm{SPI}=-2.04)$.

Generally, from 1987 to 2017 three classes of droughts were occurred in Hawassa zuria, (moderate, severe and extreme droughts) and moderate and severe droughts occurred in Hula district. The risk of livestock losses suffered during the occurrence of droughts associated with rainfall variability was one of the most serious threats to livestock herders. Drought is an extreme weather event, which results when rainfall is far below average.

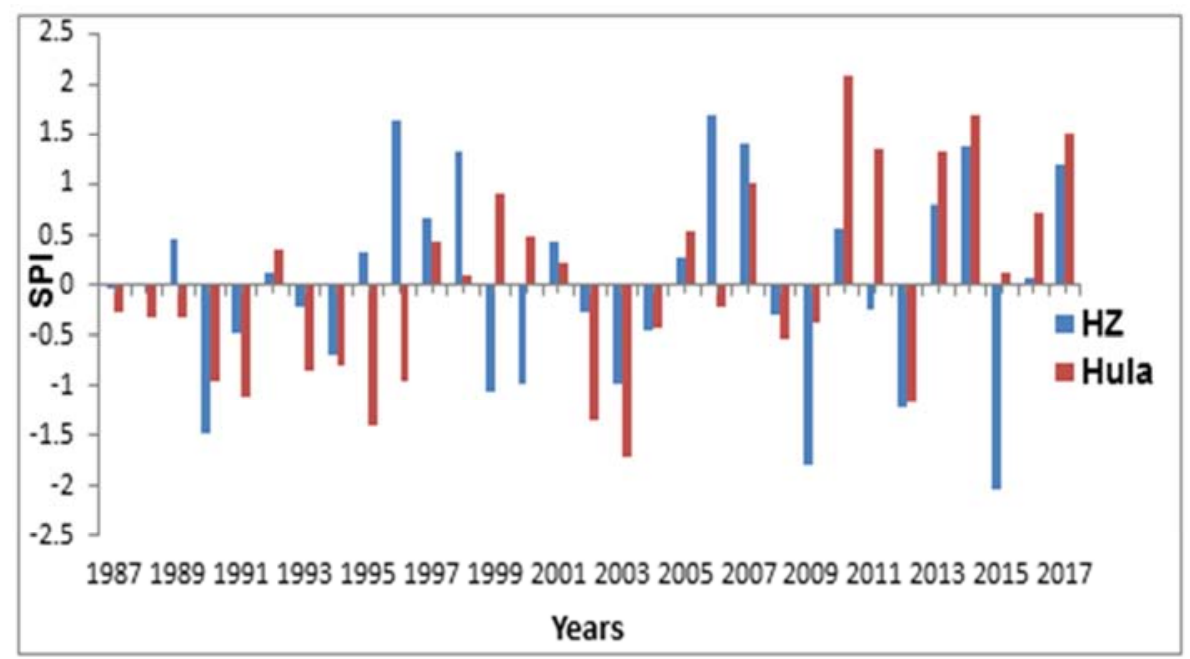

Figure 4. Standardized precipitation Index at HZ and Hula.

\subsubsection{Temperature}

Temperature is one of the elements that determine the weather condition and climate of an area. The average yearly maximum temperature of Hawassa Zuria and Hula districts were $27.5^{\circ} \mathrm{C}$ and $19^{\circ} \mathrm{C}$ respectively, while the average minimum temperature of respective districts were $13.1^{\circ} \mathrm{C}$ and $6.4^{\circ} \mathrm{C}$ in the last three decades. As indicated in figure 5 below the maximum temperature of Hawassa Zuria and Hula districts over the past 31 years were increased by about $0.03^{\circ} \mathrm{C}$ and $0.08^{\circ} \mathrm{C}$ annually respectively. This indicated that maximum temperature of Hula was increased by the faster rate than that of the Hawassa Zuria.
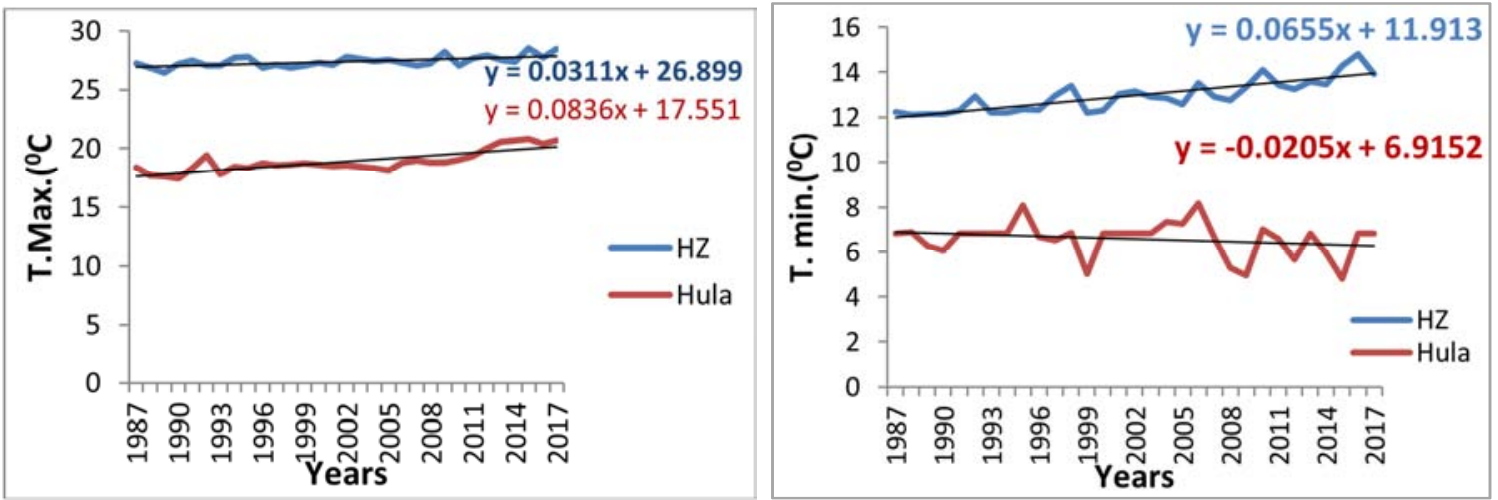

Figure 5. Trends of maximum and minimum temperature.

Average minimum temperature of Hawassa Zuria was increased by $0.06^{\circ} \mathrm{C}$, while that of Hula district was decreased by $0.02^{\circ} \mathrm{C}$ annually (Figure 5). Since 1987 temperature has been steadily increasing reaching as high as $28.6^{\circ} \mathrm{C}(2015)$ and 14.9 (2016) as for annual mean maximum and minimum temperature, respectively in Hawassa Zuria and on the other hand in Hula district, the annual mean maximum temperature reached $21^{\circ} \mathrm{C}$ (in 2015) and minimum temperature reached about $8.3^{\circ} \mathrm{C}$ (in 2006).

In Ethiopia the average annual minimum and maximum temperature over the country has been increased by the rate of $0.25^{\circ} \mathrm{C}$ and $0.1{ }^{\circ} \mathrm{C}$ every ten years, respectively [40].

\subsubsection{Trend Analysis}

Detection and attribution of past trends, and variability in climatic variables is essential for the understanding of potential future changes. The Mann-Kendall non parametric trend test was applied to time series of total annual rainfall and maximum and minimum temperature for Hawassa zuria and Hula districts. The test statistic follows the standard normal distribution. The higher the magnitude of the value of the Kendall's tau, the strong the trend is. 
Table 2. Mann-Kendall test of significance.

\begin{tabular}{lll}
\hline Variable & Mann-Kendall's tau & Sig. level \\
\hline Maximum temperature of HZ & $0.4212^{*}$ & 0.00 \\
Maximum temperature of Hula & $0.6369^{*}$ & 0.00 \\
Minimum temperature of HZ & $0.6662^{*}$ & 0.00 \\
Minimum temperature of Hula & -0.1140 & 0.36 \\
Total annual rainfall of HZ & 0.05 & 0.68 \\
Total annual rainfall of Hula & $0.3333^{*}$ & 0.01 \\
\hline
\end{tabular}

* indicates statistical significance at 5\% level

We obtained an increasing trend in the time series of in both maximum and minimum temperature in Hawassa Zuria and maximum temperature and total rainfall in Hula. Minimum temperature in Hawassa Zuria shows the strongest increasing trend.

The direction of the temperature trend in the study area was consistent with several other studies $[14,22]$ at various spatial and temporal scales have recognized warming trends in minimum and maximum temperature.

In Ethiopia, the average annual minimum temperature over the country has been increasing by $0.25^{\circ} \mathrm{C}$ every ten years while average annual maximum temperature has been increasing by $0.1{ }^{\circ} \mathrm{C}$ every decade [39].

\subsubsection{Farmers' Perceptions to Climate Change}

The farmers were asked whether they had perceived changes in the pattern of rainfall and temperature in their locality. As indicated in table 3 below, about $92.2 \%$ and $75.6 \%$ of the respondents perceived decreasing amount of rainfall in Hawassa Zuria and Hula districts respectively, while all of the respondents in both districts perceived increasing trend of temperature in the past three decades. There is also statistically significance mean difference between the two local areas respondents' perception on the trends of rainfall at 5\% significance level. Consequently, Hawassa Zuria community perceived decreasing rainfall trend more than that of Hula ( $\mathrm{t}$ - value= 3.788).

The results showed that the respondents, who noted decreasing in amount of rainfall, replied that it led to decrease in pasture production, water availability and increase disease and parasite occurrence. The amount of rainfall might increase from time to time with its intensity increased. The rainfall might come late and withdraw early. Some variations in the rainfall pattern had been experienced in the area from one year to the other over the thirty-year period. As the study conducted by Oxfam International [41] in Oromia region indicated the total number of days were decreased from 73 rainy days in 1982 to 8 rainy days in 2007 , whereas the of the total annual rainfall is more or less the same. However, when the rain comes, it is erratic leading to flooding without recharging ground water resources.

The result also indicated that the majority of the respondents noticed a change in the length of rainy season, specifically, $90.3 \%$ and $87.2 \%$ observed decreasing in length of rainy season in Hawassa Zuria and Hula respectively, whereas the remaining observed no change in the length of rainy season in respective districts.

Table 3. Perception on rainfall and temperature trend.

\begin{tabular}{|c|c|c|c|c|c|c|}
\hline \multirow{2}{*}{ Variables } & & \multirow{2}{*}{$\begin{array}{l}\text { HZ }(n=103) \\
\text { Frequency } \%\end{array}$} & \multicolumn{3}{|c|}{ Hula $(n=86)$} & \multirow{2}{*}{ t-value $(d f=187)$} \\
\hline & & & & Fre & & \\
\hline \multirow{3}{*}{ RF Amount } & Increasing & - & - & 9 & 10.4 & \multirow{3}{*}{$3.788 *$} \\
\hline & Decreasing & 95 & 92.2 & 65 & 75.6 & \\
\hline & No change & 8 & 7.8 & 12 & 14 & \\
\hline \multirow{3}{*}{ RF Pattern } & Highly variable & 54 & 52.4 & 42 & 48.8 & \multirow{3}{*}{0.2807} \\
\hline & Slightly variable & 31 & 30.1 & 33 & 38.4 & \\
\hline & No change & 18 & 17.5 & 11 & 12.8 & \\
\hline \multirow{3}{*}{ RF duration } & Prolonged & - & - & - & - & \multirow{3}{*}{0.6686} \\
\hline & Becoming Short & 93 & 90.3 & 75 & 87.2 & \\
\hline & No change & 10 & 9.7 & 11 & 12.8 & \\
\hline \multirow{3}{*}{ Onset of rainy Season } & Early & 3 & 2.9 & - & - & \multirow{6}{*}{1.4131} \\
\hline & Late & 88 & 85.4 & 63 & 73.3 & \\
\hline & On time & 12 & 11.7 & 23 & 26.7 & \\
\hline \multirow{3}{*}{ Temperature } & Increasing & 103 & 100 & 86 & 100 & \\
\hline & Decreasing & - & - & - & - & \\
\hline & No change & - & - & - & - & \\
\hline
\end{tabular}

* indicates statistical significance at 5\% level.

Various studies have demonstrated a good match with the result of perceptions of the local people in Ethiopia. Climate change and its impacts have also been perceived by local people, who express (from their indigenous knowledge and experiences) climate variability and change in that generally the temperature is increasing and the rainfall is decreasing [2, $10,30,43,55,56]$.

Generally, all the farmers in the study areas said that they were aware of climate change, mainly through their life time experiences. In general, this study presented farmers believe that the climate is changing for the bad and had led to changes in livestock productivity. Similarly, studies which assessed farmers' perception on climate change in Ethiopia have reported comparable findings.

The study conducted by Belachew and Zuberi on farmers' perception of climate change and their response in Central Oromia, indicated that farmers had a good understanding and perception of the impacts of climate change at the local level; 
many negative impacts of the climate irregularity had been identified by the community, like reduced crop yield, heating/drying up of environment and soil loss affecting natural plant regeneration from the forest soil seed bank, drying up of streams and springs, disappearance of trees and plants, rarity of wild animals and increasing pests/diseases [9].

According to the study conducted in Sidama zone, farmers clearly perceive climate change based on their lived experience and knowledge of their local environment. They identify shifting seasons, increased aridity, drought, erratic rainfall, floods, extreme heat and the emergence/spread of diseases such as malaria as indicators of change. Yet their perception of the cause of climate change varied: deforestation, God's wrath, abandonment of past traditions/practices and overpopulation [45].

\subsection{Effect of Climate Change on Livestock Production}

Climate change and its impacts on livestock was the most frequently mentioned problems by the herders of Hawassa Zuria and Hula districts. Respondent in the study areas indicated that climate change had its effect on their livestock production through various mechanisms. The importance of climate change observed on livestock production system in the study areas is demonstrated in tables 4 and 5 .

Lack of feed due to drought, flood and unpredictable rainfall; increased disease incidence; and shortage of water due to drought were responded in varied degree between the households of Hawassa Zuria and Hula districts (74.75 vs 86.05 ; 9.5 vs 13.95 and 15.5 vs 0$) \%$ respectively. As a result of the observed changes and increased frequency of climate hazards, livestock feed availability has tremendously reduced.

Moreover, FGD participants in Hula suggested other factors for the increased shrinkage of rangeland area and deterioration of productivity. These include expansion of farming and overgrazing.

The amount and duration of rainfall is declining and the dry season is becoming longer, resulted in shortage of water and pasture that further led to the loss of livestock assets [7]. Furthermore, the effect of climate change on livestock production is measured through the effects on natural pastures, water sources, livestock diseases and biodiversity [5, 28, 38, 42].

Climate change and its impacts on livestock were the major problems to the herders of Hawassa Zuria and Hula districts. Most of the respondents agreed that the quantity and quality of the pastures was deteriorating. This is mostly because of shortage and variability of rainfall. Generally, farmers believe that the decreasing livestock production and reproduction trends were associated with shortages of feed and resulted in poor livestock performance. Changes in rainfall patterns affects pasture growth patterns thereby affecting the quality and quantity of both feed grains and fodder produced.

Similar results were obtained from the FGD from Hula decrease in amount of rainfall that it led to a decrease in pasture production, increase disease and parasite occurrence. Livestock feeds are desperately decreased in quantities and qualities. Areas which were earlier used to serve as pasture lands for livestock grazing and browsing of animals in farming communities have currently shrunk and converted into farmlands because of great pressure imposed from lands for crop cultivations.

Climate change is likely to bring about even more erratic and unpredictable rainfalls and more extreme weather conditions such as longer and frequent droughts. As a result, access to pastures becomes more difficult, leading to loss of livestock. The trends in inter-annual and inter-seasonal rainfall variability like declining in amount, increasing in intensity, varying in the length of growing seasons with increasing temperature are consequently negative effect on livestock productivity [23, 31].

The increased drought and the rise in temperature adversely affect pastoral livestock production through pose thermal stresses on animals; impair feed intake, and thereby hindering their production and reproductive performances and disease distributions. Reduction of quantity and quality of feed often results in declining the animal production [19, 28].

Table 4. Factors affecting animal feed in HZ and Hula.

\begin{tabular}{llrlrl}
\hline Factors & \multicolumn{2}{l}{$\begin{array}{l}\text { HZ }(\mathbf{n}=\mathbf{1 0 3}) \\
\text { Frequency } \%\end{array}$} & \multicolumn{2}{l}{$\begin{array}{l}\text { Hula }(\mathbf{n}=\mathbf{8 6}) \\
\text { Frequency \% }\end{array}$} & $\begin{array}{l}\text { t-value } \\
(\mathbf{d f}=187)\end{array}$ \\
\hline Drought & 38 & 36.9 & - & - & $6.4752^{*}$ \\
Flood & 19 & 18.4 & 21 & 24.48 & 0.6958 \\
RF Variability & 20 & 19.4 & 53 & 61.62 & $5.6633^{*}$ \\
\hline
\end{tabular}

* indicates statistical significance at 5\% level.

As ranked by respondents, major effects of climate change on livestock production include reduced quality and quantity of feed, incidence of diseases, reduced quality and quantity of water and reduced production and reproduction performance of the animals (table 5). Changes in rainfall patterns affects pasture growth patterns thereby affecting the quality and quantity of both feed grains and fodder produced.

Perceptions of flooding were dominated by two divergent viewpoints. Majority of the respondents (table 3 ) felt that the amount of rainfall had decreased, whereas $18.4 \%$ in $\mathrm{HZ}$ and $24.48 \%$ in Hula claimed that flooding had actually become more frequent and affecting feed (table 4), as rainfall became more erratic and intense with short-lasting storms.

Generally, most of respondents ranked that reduction of quality and quantity of feed was the primary impact of climate change in both districts. Grazing livestock is negatively affected by climate change. The availability of pasture and water for livestock is determined by climate conditions and land use change. Natural grass was the main feed for cattle in the study areas. High temperature and lacking of water reduced grass development capacity or even made nature grass drier or died. The impacts of increased climate change on livestock production are likely to increase the risk of production and productivity losses. 
Table 5. Rank of major impacts of climate change on livestock production.

\begin{tabular}{lllll}
\hline \multirow{2}{*}{ Major impacts } & HZ & \multicolumn{3}{c}{ Hula } \\
\cline { 2 - 5 } & Index & Rank & Index & Rank \\
\hline Reduced quality and quantity of feed & 0.2799 & $1^{\text {st }}$ & 0.4376 & $1^{\text {st }}$ \\
Reduced production performance & 0.2443 & $2^{\text {nd }}$ & 0.1564 & $4^{\text {th }}$ \\
Increased incidence of diseases & 0.2427 & $3^{\text {rd }}$ & 0.2475 & $2^{\text {nd }}$ \\
Reduced quality and quantity of water & 0.1602 & $4^{\text {th }}$ & - & - \\
Reduced reproduction performance & 0.0728 & $5^{\text {th }}$ & 0.1584 & $3^{\text {rd }}$ \\
\hline
\end{tabular}

Climate change is likely to have major impacts on poor livestock keepers and on the ecosystem goods and services which they depend on. These impacts will include changes in the productivity of forage, reduced water availability, and changing severity and distribution of livestock diseases. Changes in the patterns of rainfall and ranges of temperature affect feed availability, grazing ranges, feed quality, quantity and quality of water, weed, and pest and disease incidence. The spatial distribution and availability of pasture and water are highly dependent on the pattern and availability of rainfall $[6,10,20,46,52,53]$.

Occurrence of diseases is one of the major problems ranked by the respondents. This is associated to increased susceptibility of livestock to diseases aggravated by shortage of feed. Drought affected livestock by drying water

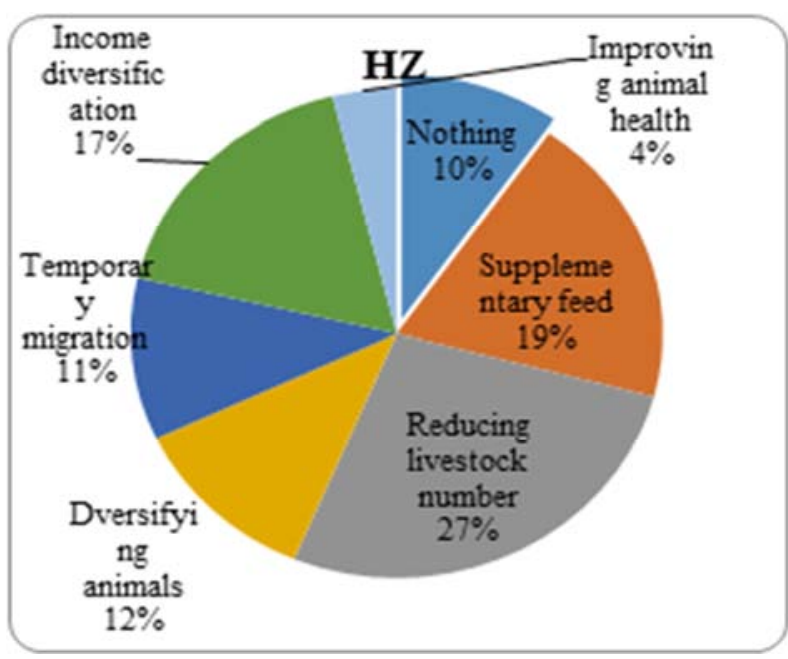

resources, pasture land and decreasing availability of drinking water to livestock.

The direct effect of extreme weather variability causes significant effect on animal health, growth and reproduction. The effects from feed resources causes were due to change in forage species composition that brought a significant effect on type of animal species or category feed on it and eventually modifies the feeding pattern this was due to the change in quality of forage by increased temperature and reduce the rate of degradability of species which further reduce nutrient availability to animals [44].

Although the direct effects of heat stress on livestock have not been studied in the study areas, increased heat alters feed intake, growth, reproduction and production of animals. Thus, the collective effects of these factors were likely to have a negative impact on livestock productivity in the areas.

\subsection{Adaptation Measures}

Farmers were asked which climate change adaptation measure they have been using so far. Thus, the result was shown using a pie chart below which indicates the farmers' adaptation strategies taken to reduce the impact of climate change (figure 6).

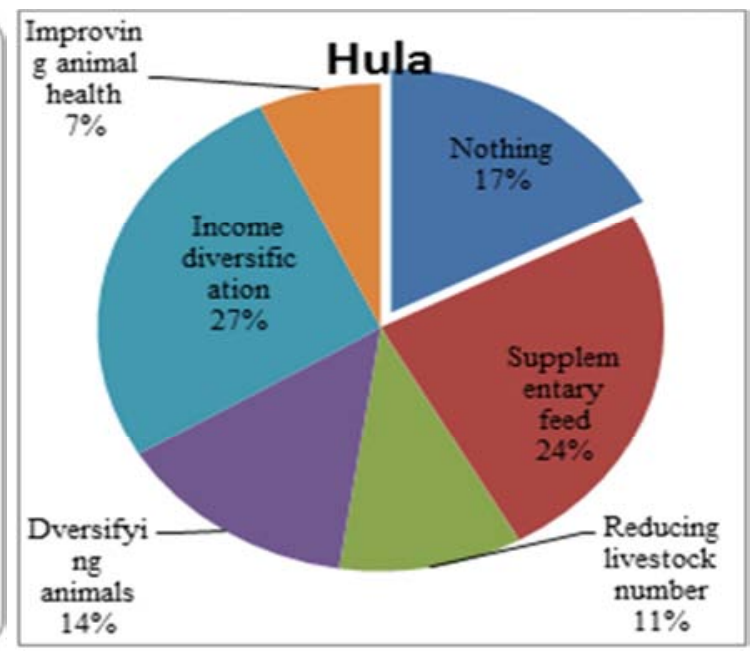

Figure 6. Adaptation strategies used by the farmers in HZ and Hula.

In this case, reducing the number of animals is preferred climate change adaptation strategy as it is indicated by $27 \%$, followed by supplementary feed (by 19\%) and income diversification (by 17\%) in Hawassa Zuria. whereas, income diversification is the primary adaptation method (27\%) followed by supplementary feed $(24 \%)$ in Hula district.

In Central Oromia farmers were observed to diversify their livelihood options as part of responding to irregularities in the local weather and adopting a number of steps to change agricultural systems [9].

The above chart shows that, about $89.32 \%$ and $82.56 \%$ of the respondents from lowland (Hawassa Zuria) and highland (Hula) AEZ has taken different adaptation measures to climate change respectively, while the remaining $10.68 \%$ and $17.44 \%$ did not. As compared to the farmers between lowland and highland AEZs, the respondents who has taken adaptation measures from highland AEZ are relatively lower. This is may be due to the fact that the intensity of climate change effects gets lower and lower as one goes from lowlands to highlands. Therefore, this proportion could also be an indicator of where the climate change effects is more sever.

\subsection{Factors Affecting Adaptation Choices}

The results of MNL model shows how factors influence farmers' choice of adaptation measures in the study area. Therefore, tables 6 and 7 below presents the MNL results along with the levels of statistical significance.

MNL regression shows the determinant variables for each category versus the reference category. The reference category is the household who did not choose any adaptation 
strategy. The maximum likelihood method was employed to

farmers' decision to choose adaptation measures.

estimate the relative importance of predictor variables on the

Table 6. Marginal effects from the multinomial logit climate change adaptation model; HZ.

\begin{tabular}{llllllll}
\hline Explanatory Variable & $\begin{array}{l}\text { Supplementa } \\
\text { ry feed }\end{array}$ & $\begin{array}{l}\text { Reducing } \\
\text { livestock number }\end{array}$ & $\begin{array}{l}\text { Diversifying } \\
\text { animals }\end{array}$ & $\begin{array}{l}\text { Temporary } \\
\text { migration }\end{array}$ & $\begin{array}{l}\text { Income } \\
\text { diversification }\end{array}$ & $\begin{array}{l}\text { Improving } \\
\text { animal health }\end{array}$ & No adaptation \\
\hline Gender & 1.6515 & -.5816 & -.4155 & -.4166 & -.4169 & .3909 & -.2117 \\
Education & .0698 & .0104 & .0145 & .0081 & .0217 & -.0345 & -.0902 \\
Labour & .0365 & -.0409 & .0054 & -.0648 & $.1560^{*}$ & -.0438 & -.0484 \\
Farm size & -.0284 & -.0754 & $.0787 * *$ & -.0180 & .0276 & .0104 & .0050 \\
TLU & -.0593 & .0331 & -.0380 & $.1267 *$ & .0279 & -.0248 & -.0656 \\
Information & .2122 & .3812 & .2806 & .1306 & .1581 & .0860 & -1.249 \\
Experience & -.0268 & $.3009 *$ & -.0623 & -.0420 & -.0320 & -.0743 & -.0632 \\
Saving & .5667 & .2556 & .2213 & .2537 & .2789 & -.4415 & -1.134 \\
\hline
\end{tabular}

Notes: $* * *=$ significant at $1 \%$ and $5 \%$, probability level, respectively.

Table 7. Marginal effects from the multinomial logit climate change adaptation model; Hula.

\begin{tabular}{|c|c|c|c|c|c|c|}
\hline $\begin{array}{l}\text { Explanatory } \\
\text { Variable }\end{array}$ & $\begin{array}{l}\text { Supplementary } \\
\text { feed }\end{array}$ & $\begin{array}{l}\text { Reducing livestock } \\
\text { number }\end{array}$ & $\begin{array}{l}\text { Diversifying } \\
\text { animals }\end{array}$ & $\begin{array}{l}\text { Income } \\
\text { diversification }\end{array}$ & $\begin{array}{l}\text { Improving animal } \\
\text { health }\end{array}$ & No adaptation \\
\hline Gender & -.2926 & -.1199 & -.1382 & -.0326 & .8094 & -.2260 \\
\hline Education & $.2813^{*}$ & $.1125^{* *}$ & -.1303 & -.0387 & -.0213 & $-.2034 * * *$ \\
\hline Farm size & -.0699 & .0045 & $.1450 *$ & -.0279 & -.0330 & -.0186 \\
\hline TLU & .0554 & -.0575 & .1082 & .0202 & -.0517 & -.0745 \\
\hline Information & .0400 & -.0547 & -.0474 & .1226 & .0168 & -.0773 \\
\hline Saving & .4406 & -1.278 & .3765 & .5319 & -.5679 & .5690 \\
\hline
\end{tabular}

Notes: ${ }^{* *}, * * *=$ significant at $1 \%, 5 \%$, and $10 \%$ probability level, respectively

\section{Interpretation of significance from the marginal effect}

Education level of the household head: When the education level of the household is increased by one, the probability of engaging supplementary feed and reducing number of animals as adaptation strategies increased by $28.14 \%$ and $11.25 \%$ at $1 \%$ and $5 \%$ significant level respectively in Hula district holding other variables constant. While, education level increases by one the probability of farmers' no to use any adaptation strategy decrease by $20.34 \%$ at $10 \%$ level of significance, keeping other variables constant in Hula.

Evidence from sources indicates that there is a positive relationship between the education level of the head of household and adaptation to climate change [13]. Therefore, farmers with higher levels of education are more likely to adapt better to climate changes

Active labour: Labour also has significant and positive effect on adaptation strategies to climate change in both districts. A unit increase of active labour in the family increase the probability of farmers to use income diversification adaptation methods by $15.6 \%$ and $18.74 \%$ in Hawassa Zuria and Hula districts respectively at $1 \%$ significant level, keeping other variables constant. Because larger household size enables the adoption of technologies by availing the necessary labour force in one hand and enabling the generation of additional income from extra labour invested in off-farm activities. The finding of this study was similar with the result of Tagel [50].

Farm size: Farmers' adaptation strategy to climate change is also significantly affected by the amount of farm size that the households owned. For instance, a one hectare increases in the farm size increases the probability of the farmers to use diversifying animal species and genetic resources adaptation strategies by $7.88 \%$ and $14.5 \%$ in Hawassa Zuria and Hula respectively, holding other variables constant.

Farm size may also associate with greater wealth and it is hypothesized to increase adaptation $[1,21,51]$.

This indicates that the bigger the size of the farm, the greater the proportion of pasture land allocated for different animal species as some adaptation strategies that the farmers are likely to adopt.

Livestock holding: The number of the livestock owned by the farmer is significant explanatory variable in this study. It was positively influencing the farmers' decision of taking diversifying animal resources in Hula as well as temporary migration in Hawassa Zuria. A one TLU increase in the livestock owned by the household increases the probability of temporary migration by $12.67 \%$ in Hawassa Zuria and diversifying animal resource in Hala by $10.82 \%$.

In this case, livestock is considered as an asset for the farmers and plays a very important role by serving as a source of income. Therefore, having a large number of livestock can strengthen farmers' adaptive capacity to climate change. On the other hand, livestock rearing is one part of agricultural activities which is also subject to climate change impact. Consequently, as the number of the livestock increased the farmers will look for adaptation measures that safeguard their assets against climate related problems. This result is also similar with Legesse et al. [33]. When climate changes are getting more current in arid and semi-arid regions, temporary migration in search for livestock might become a valuable adaptation strategy [48] 
Farm experience: It is one of a significant explanatory variable in which its coefficient has positive sign. A year increase in age of the household head increases the probability of farmers to use reducing animal numbers as adaptation measure by $30.09 \%$ at $1 \%$ significant level and $11.39 \%$ at $10 \%$ significant level in Hawassa Zuria and Hula districts respectively, other factors remain constant.

The likelihood of taking up climate adoption measures was higher among older farmers. Because as the age of the household head increases, the person is expected to acquire more experience in weather forecasting and that helps increase in likelihood of practicing different adaptation strategies to combat impacts of climate change on livestock production.

This might be attributed to the experience of older farmers perceiving changes in climatic attributes. This result is in line with the findings of Ajibefun and Fatuase [4] On the other hand, due to things like a weaker health, and consequently age and experience might give negative outcomes [48].

\section{Conclusion}

The study used cross-sectional data collected from 189 households in the production year 2017/2018, and applied descriptive and econometric approaches to analyze the data. In this study area, almost all of the livestock keepers have awareness about the change in the level of precipitation and temperature during the last 30 years in both Hawassa Zuria and Hula districts. Majority of the respondents, about $92.2 \%$ in Hawassa Zuria and $75.6 \%$ of Hula perceived reduction in amount of rainfall. Meteorological recorded data of the areas showed in contrary of the most farmers' perception and indicate an increasing trend in rainfall in 31 years' period in both districts. This lack of congruence between farmers' perception and Meteorological data is due to the fact that farmers assess rainfall in relation to the needs of particular crops at particular growing seasons. All of the respondents perceived increment in temperature over the last 20 years. Indicators of climate change have been observed in the study area includes: drought, flood, as well as rainfall variability.

Farmers in the study area have encountered climate related problems like feed quality and availability, water quality and availability, risk of animal diseases and hence, reduced performance of animals.

Majority of the livestock herders have been practicing different adaptation measures like income diversification, supplementary feed, reducing number of animals, diversifying animals in both districts. Education, age, labor size, farm size of household and livestock holding are the determents of adaptation measures in the study area.

\section{Recommendations}

Based on the findings of this study, the following recommendations were forwarded to help the livestock farmers in the highlands and lowlands of Sidama region to tackle climate change impacts and farm productively.

1. Improve the quality of meteorological data and increase the spatial distribution of stations.

2. The vulnerability of lowlands is a grave concern in future and intervention is needed to address water shortage in Hawassa zuria district.

3. Promote use of improved forage species with good nutritive value and which can resist the impact of climate change.

4. Facilitate research and extension services to provide adequate extension and information services to ensure that farmers receive up-to date information about rainfall and temperature patterns in the forthcoming seasons.

5. The study further suggests that the positive and significant variables (i.e. livestock ownership, education level, farm size, and active labor) which prompted the farmers to adapt to climate change be considered when adaptation strategies are implemented.

\section{Acronyms and Abbreviation}

$\begin{array}{ll}\text { AEZs } & \text { Agro-ecological Zones } \\ \text { CV } & \text { Coefficient of Variation } \\ \text { CSA } & \text { Central Statistical Agency } \\ \text { EPCC } & \text { Electric Power Control Centres } \\ \text { FAO } & \text { Food and Agriculture Organization } \\ \text { HZ } & \text { Hawassa Zuria } \\ \text { IPCC } & \text { Intergovernmental Panel on Climate Change } \\ \text { MNL } & \text { Multinomial Logit Model } \\ \text { NMA } & \text { National Meteorology Agency } \\ \text { ONRS } & \text { Oromia National Regional State } \\ \text { SD } & \text { Standard Deviation } \\ \text { SPI } & \text { Standardized Precipitation Index } \\ \text { SPSS } & \text { Statistical Packages for Social Scientists } \\ \text { TLU } & \text { Tropical Livestock Unit } \\ \text { WFP } & \text { World Food Program } \\ \text { WISP } & \text { World Initiative for Sustainable Pastoralism }\end{array}$

\section{References}

[1] Aababbo Y, Sawore A. (2016). Assessing Determinant Factors of Income Diversification among Rural Farm Households in Ethiopia: The Case of Leemo and Anileemo Districts, Hadiya Zone, South Nation Nationalities People Region. International Journal of Science and Research (IJSR) 5 (12): 100-110.

[2] Addisu S., Fissha G., Gediff B. and Asmelash Y. (2016). Perception and adaptation models of climate change by the rural people of Lake Tana Sub-Basin, Ethiopia. Environ. Syst. Res. 5: 1-10.

[3] Addisu S., Gebreselassie Y., Fissha G. and Gedif B. (2015). Time series trend analysis of temperature and rainfall in Lake Tana Sub-Basin, Ethiopia. Environ. Syst. Res. 4: 1-12.

[4] Ajibefun, A. and Fatuase, A. (2011). Analysis of Perception Adaptation to Climate Change Among Arable Crop Farmers in Ikogosi Warm Spring Communities of Ekiti State, Nigeria. 
[5] Aklilu, A., Desalegn, W., Mesfin, K. and Negash, T. (2013). Climate change impacts on Pastoral Women in Ethiopia: Some evidences from the Southern lowlands. PHE Ethiopia Consortium. 1-6p.

[6] Alemayehu A. and Bewket W. (2016). Vulnerability of smallholder farmers to climate change and variability in the central highlands of Ethiopia. Ethiop. J. Soc. Sci. Human. 12 (2): $1-24$.

[7] Ayana, S., et al. (2011). Agriculture Sector Programme of Plan on Adaptation to Climate Change, Technical working group, Addis Ababa.

[8] Bekele, S. (2017). Impacts of Climate Change on Livestock Production: A Review: Wolaita Sodo University, Journal of Natural Sciences Research www.iiste.org ISSN 2224-3186 (Paper) ISSN 2225-0921. Vol. 7, No. 8, 2017.

[9] Belachew, O. and Zuberi, I. M. (2015). Perception of Climate Change and Livelihood of a Farming Community of MarufKebele, Central Oromia, Ethiopia. American Journal of Climate Change, 2015, 4, 269-281. Ambo University, Ambo, Ethiopia.

[10] Belay A., Recha J. W., Woldeamanuel T. and Morton J. F. (2017). Smallholder farmers' adaptation to climate change and determinants of their adaptation decisions in the Central Rift Valley of Ethiopia. Agriculture and Food Security. 6: 1-13.

[11] Bewket W. (2011). On being climate ready: Climate change strategy for Ethiopia, Policy Brief \#4, Addis Ababa: Forum for Environment.

[12] Challinor A, Watson J, Lobell D, Howden S, Smith D. and Chhetri N. (2014) A meta-analysis of crop yield under climate change and adaptation. Nature Climate Change 4: 287-291.

[13] Debele. B, and Desta, G. (2016). Livelihood Diversification: Strategies, Determinants and Challenges for Pastoral and Agro Pastoral Communities of Bale Zone, Ethiopia. International Review of Social Sciences and Humanities 11 (20): 37-51.

[14] Degefu M. A and Bewket W. (2014). Variability and trends in rainfall amount and extreme event indices in the Omo-Ghibe River Basin, Ethiopia. Reg Environ Change 14: 799-810. doi: 10.1007/s10113-013-0538-z.

[15] Di Falco S. and Veronesi M. (2013) How can African agriculture adapt to climate change? A counterfactual analysis from Ethiopia. Land Economics 89 (4): 743-766.

[16] EPCC. (2015). First Assessment Report, Working Group II Agriculture and Food Security. Published by the Ethiopian Academy of Sciences.

[17] Eshetu Z. (2011). Climate variability in Ethiopia and global greenhouse gases emission. In: Kelbessa E. and Girma A. (eds.). Multiple roles of forests in Ethiopia versus associated challenges: Maximizing benefits while curbing limitations. In Commemoration of 3rd National Mother Earth Day and 2011 International Year of Forests. Forum for Environment, Addis Ababa. Pp. 25-37.

[18] FAO. (2010h). Status and Trends of Animal Genetic Resources 2010. CGRFA/WG-AnGR-6/10/Inf.3. Rome.

[19] Fereja, G, B. (2016). The impacts of climate change on livestock production and productivities in developing countries. International Journal of Research. Gambella University, Gambella, ETHIOPIA. Vol. 4.
[20] Gebrehiwot T. and van der Veen A. (2013). Climate change vulnerability in Ethiopia: disaggregation of Tigray region. Journal of Eastern African Studies. 7 (4): 607-629.

[21] Gecho, Y. (2017). Rural Farm Households' Income Diversification: The Case of Wolaita Zone, Southern Ethiopia. Social Sciences. 6 (2): 45-56. Doi 10.11648/i.ss20170602.12. Crossref.

[22] Gedefaw M, Girma A, Denghua Y, Hao W, Agitew G. (2018). Farmer's Perceptions and Adaptation Strategies to Climate Change, Its Determinants and Impacts in Ethiopia: Evidence from Qwara District. J Earth Sci Clim Change 9: 481. Doi: $10.4172 / 2157-7617.1000481$

[23] Getachew, H. and Tesfaye, K. (2015). Analysis of Risks in Crop Production due to Climate Change I the Central Rift Valley of Ethiopia. African Journal of Agricultural Research. Vol 10 (16), pp 1913-1922.

[24] Greene, H. W. (2003). Econometric Analysis, 5th Edition, Pearson Education, Inc., Upper Saddle River, New Jersey, USA, P. 720-723.

[25] Haileab Z. (2018). Climate change in Ethiopia: impacts, mitigation and adaptation. International Journal of Research I Environmental Studies. ISSN 2059-1977.

[26] Hayelom, M. A. (2016). Review on the Impact of Climate Change on Livestock Production and Genetic Diversity. Adigrat University, Adigrat, Ethiopia. Volume 4, Issue 2 | ISSN: 2321-9939.

[27] Herrero, M., et al. (2010). Smart investments in sustainable food production: revisiting mixed crop-livestock systems. Science 327, 822-825.

[28] Hoffmann, I. (2010). Climate Change and the Characterization, Breeding and Conservation of Animal Genetic Resources. Animal Genetics Resources, FAO, 41 (Suppl. 1), 32-46.

[29] IPCC. (2007). Climate Change 2007: Synthesis Report. Contributions of Working Groups i, ii, and iii to the Fourth Assessment Report of the Intergovernmental Panel on Climate Change. Geneva: IPCC.

[30] Kassa M. (2013). Farmers' perception of climate change and local adaptation strategies in the highlands of Ethiopia: the case of Menz Gera Midir, Amhara region, Ethiopia. In: Workeneh S, Dechassa N, Ketema M and Belayneh A (eds.), Proceedings of the International Conference on Biodiversity Conservation and Ecosystem Services for Climate Change Mitigation and Sustainable Development. Haramaya University (HU), Haramaya and United Nations Development Programme (UNDP). Pp. 242-253.

[31] Kassie, B. et al. (2012). Climate variability and change in the Central Rift Valley of Ethiopia: challenges for rain-fed crop production. Climate Change and Agriculture Research Paper. Journal of Agricultural Science Page 1 of 17. Cambridge University press 2013 Livestock and global climate change international conference proceedings, Tunisia, 17-20.

[32] Kebede, D. and Adane, H. (2011). Climate change adaptations and induced farming livelihoods. DCG Report No. 64.

[33] Legesse, B., Yared A. and Bewket W. (2012). Smallholder Farmers' perception and adaptation to climate variability and climate change in Doba district, Western Hararghe, Ethiopia. Asian Journal of Empirical research, 3 (3): 251-265. 
[34] LIVES. (2013). Zonal diagnosis and intervention plan. Sidama zone, SNNP Region. Hawassa, Ethipia.

[35] McKee, T. B., Doesken, N. J., Kleist, J. (1993). The relationship of drought frequency and duration to time scale. In: Proceedings of the Eighth Conference on Applied Climatology, Anaheim, California, 17-22 January 1993. Boston, American Meteorological Society, 179-184.

[36] Milan and Slavisa. (2012). Analysis of Changes in Meteorological Variables Using Mann-Kendall and Sen's Slope estimator statistical tests in Serbia. Global and Planetary Chnge. Elsevier. B. V.

[37] Naqvi, S. M. K. and Sejian, V. (2011). Global Climate Change: Role of Livestock. Asian Journal for Agricultural Science, 3 (1), 19-25.

[38] Nardone A, Ronchi B, Lacetera N, Ranieri MS, Bernabucci U. (2010). Effects of climate change on animal production and sustainability of livestock systems. Livest. Sci. 2010; 130: 5769.

[39] NMA. (2009). Seasonal Agro meteorological Bulletin. Belg 2009. Volume 19 No. 15.

[40] ONRS. (2011). Program of Plan on Adaptation to Climate Change. February, 2011. Finfinne (Addis Ababa). 97p.

[41] Oxfam. (2010). The rain doesn't come on time any more: poverty, vulnerability and climate variability in Ethiopia. Oxfam: Addis Ababa.

[42] Pilling D. and Hoffmann I. (2011). Climate Change and Animal Genetic Resources for Food and Agriculture: State of Knowledge, Risks and Opportunities. Background Study Paper No. 53.

[43] Riché B., Hachileka E., Awuor C. and Hammil A. (2010). Climate related vulnerability and adaptive capacity in Ethiopia's Borena and Somali communities: summary of findings. In: Assefa F and Girmay W (eds.), Proceedings of a National Workshop on Climate Change: Challenges and opportunities for adaptation in Ethiopia. The Biological Society of Ethiopia, Addis Ababa University, Addis Ababa. Pp. 21-29.

[44] Robinson S, Strzepek K and Cervigni R (2013). The Cost of Adapting to Climate Change in Ethiopia: SectorWise and Macro-Economic Estimates. ESSP working paper 53. 1-23.

[45] Seyoum, H. (2015). Perceptions, vulnerability and adaptation to climate change in Ethiopia: The case of smallholder farmers in Sidama (Unpublished PhD Thesis). School of Social Sciences, University of East London.

[46] Simane B., Zaitchik B. F. and Foltz J. D. (2016). Agroecosystem specific climate vulnerability analysis: application of the livelihood vulnerability index to a tropical highland region. Mitigation and Adaptation Strategies for Global Change. 21: 39-65.

[47] Solomon, T and Firew, T. (2018). Impacts of climate change on livestock production and productivity and different adaptation strategies in Ethiopia. Journal of Applied and Advanced Research, 2018: 3 (3) $52-58$ http://dx.doi.org/10.21839/jaar.2018.v3i3.150

[48] Sørhaug, A. K. (2011). Climate Change Impacts and Adaptations among Ethiopian Farmers Case studies of Hagere Selam, Tigray, and Kofele, Oromia. University of Agder.
[49] Stark, J., Terasawa, K. and Ejigu, M. (2011). Climate Change and Conflict in Pastoralist Regions of Ethiopia: Mounting Challenges, Emerging Responses. CMM Discussion Paper No. 4. October 2011. pp. 154.

[50] Tagel, G. (2013). Farm Level Adaptation to Climate Change: The Case of Farmer's, in the Ethiopian Highlands, Environmental Management (2013) 52: 29-44 DOI 10.1007/s00267-013-0039-3.

[51] Tamerat, T. (2016). Livelihood Resources and Determinants in Tigray Region of Ethiopia. International Journal of Lean Thinking 7 (2): 57-66.

[52] Teshome M. (2016). Rural households' agricultural land vulnerability to climate change in Dembia Woreda, Northwest Ethiopia. Environ. Syst. Res. 5 (14): 1-18.

[53] Tesso G., Emana B. and Ketema M. (2012). Analysis of vulnerability and resilience to climate change induced shocks in North Shewa, Ethiopia. Agric. Sci. 3 (6): 871-888.

[54] Thornton, P. K. (2010), Livestock production: recent trends, future prospects. Philosophical Transactions of the Royal Society of London, Series B: Biological Sciences, 365, pp. 2853-67.

[55] Tilahun M., Angassa A. and Abebe A. (2017). Communitybased knowledge towards rangeland condition, climate change, and adaptation strategies: the case of Afar pastoralists. Ecological Processes. 6: 29. DOI: 10.1186/s13717-017-00944.

[56] Troeger S. (2010). Features of climate change in Ethiopia transforming forces on livelihood constituents and social cohesion. In: Assefa F and Girmay W (eds.), Proceedings of a National Workshop on Climate Change: Challenges and opportunities for adaptation in Ethiopia. The Biological Society of Ethiopia, Addis Ababa University, Addis Ababa. Pp. 54-67.

[57] Umer M. (2010). History of climate change and past adaptations in northeastern African region: lessons for the future. In: Assefa F and Girmay W (eds.), Proceedings of a National Workshop on Climate Change: Challenges and opportunities for adaptation in Ethiopia. The Biological Society of Ethiopia, Addis Ababa University, Addis Ababa. Pp. 15-20.

[58] United Nations Economic Commission for Africa. (2011). Climate Change and Health Across Africa: Issues and Options. African Climate Policy Centre. Working Paper 20.

[59] Watson, B. (2010). Climate change: An environmental, development and security issue. Livestock and global climate change international conference proceedings, Tunisia, 17-20 May 2008, 6-7.

[60] WFP. (2014). Ethiopia Comprehensive Food Security and Vulnerability Analysis (CFSVA). Addis Ababa, Ethiopia.

[61] WISP. (2010). Building climate change resilience for African livestock in sub-Saharan Africa. A program of IUCN, Eastern and Southern Africa Regional Office, Nairobi, March 2010, viii.

[62] WMO. (2012). Standardized Precipitation Index User Guide. Weather-Climate-Water No. 1090. Geneva 2, Switzerland. 